\title{
The Role of Obesity-Induced Inflammation in Pancreatic $\beta$-Cell Dysfunction and Death
}

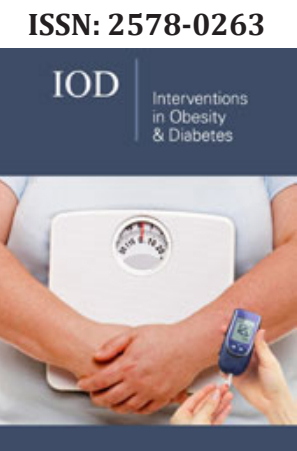

*Corresponding author: Danielle Melloul, Department of Endocrinology, Hadassah University Hospital, Jerusalem, Israel

Submission: 㭗 February 05, 2020

Published: 此April 14, 2020

Volume 3 - Issue 5

How to cite this article: Danielle Melloul. The Role of Obesity-Induced Inflammation in Pancreatic $\beta$-Cell Dysfunction and Death. Interventions Obes Diabetes 3(5). IOD.000573. 2020.

DOI: 10.31031/IOD.2020.03.000573

Copyright@ Danielle Melloul. This article is distributed under the terms of the Creative Commons Attribution 4.0 International License, which permits unrestricted use and redistribution provided that the original author and source are credited.

\author{
Danielle Melloul* \\ Department of Endocrinology, Hadassah University Hospital, Israel
}

\begin{abstract}
Type 2 diabetes (T2DM) is frequently associated with elevated levels of lipids, in particular plasma free fatty acids and toxic lipid metabolites in muscle, liver, adipocytes, pancreatic islets and arterial tissues, contributing to insulin resistance and pancreatic islet $\beta$-cell dysfunction. The pathophysiology of T2DM is increasingly being linked with inflammatory mediators such as cytokines and chemokines as well as with changes in the number and activation state of macrophages/monocytes leading to $\beta$-cell dysfunction and subsequently to insulin insufficiency. The prevalent product of the cyclooxygenase 2 (COX-2) enzyme PGE2, controls numerous physiological functions through a family of cognate G proteincoupled receptors (EP1-EP4). The EP3 receptor which is selectively upregulated in islets of T2DM individuals, is upregulated under lipotoxic conditions and is involved in $\beta$-cell dysfunction and demise. This EP3 target presents a new approach to delay the progression of T2DM disease by preserving the pancreatic $\beta$-cells.
\end{abstract}

Keywords: Diabetes mellitus; Obesity; Pancreatic islet $\beta$-cell; Inflammation; Palmitate; Apoptosis;

\section{Introduction}

Obesity is a growing and serious epidemic in the modern society leading to the development of multiple disorders including Type 2 diabetes mellitus (T2DM). The progression from obesity-related insulin resistance to T2DM implicates a failure of pancreatic $\beta$-cells to compensate for insulin resistance, leading to chronic hyperglycaemia. In early stages, $\beta$-cells adapt to changes in insulin sensitivity by varying insulin secretion. However, in susceptible subjects, when $\beta$-cells fail to compensate for insulin resistance, T2DM ensues [1]. As nutrient excess persists, hyperglycemia (glucotoxicity) and elevated free fatty acids (FFAs, lipotoxicity) contribute to $\beta$-cell failure and subsequent apoptosis [2,3]. It has been reported that most individuals with T2DM, whether obese or lean, show a decrease in $\beta$-cell mass $[4,5]$. Since pancreatic $\beta$-cell dysfunction and destruction are the key events in the onset and progression of the disease, this review will focus on the contribution of obesity-related inflammatory mediators to these processes. T2DM is associated with increased plasma free fatty acid (FFA) levels, accumulation of toxic lipid metabolites in muscle, liver, adipocytes, $\beta$-cells and arterial tissues contributes to insulin resistance and $\beta$-cell dysfunction [6-8]. While fatty acids acutely enhance glucose-induced insulin secretion [9], chronic exposure to mainly saturated FFAs causes $\beta$-cell failure and contributes to diabetes development in genetically predisposed individuals. Subjects with high fasting levels of plasma FFAs have an elevated risk of developing T2DM $[10,11]$. Furthermore, lipid infusion in individuals who are genetically predisposed to T2DM induces hepatic insulin resistance and impairs $\beta$-cell function [11].

Cumulative evidence indicates that FFAs can induce $\beta$-cell dysfunction and death through multiple mechanisms, including oxidative stress, ceramide formation, ER stress and inflammation (reviewed) [12-14]. Systemic low-grade inflammation is a hallmark feature of obesity and was suggested to play a role in T2DM. Inflammatory mediators have been shown to be involved in the pathogenesis of obesity-related insulin resistance, the development of the disease and its complications with insulin-sensitive peripheral tissues being themselves sites of inflammation in presence of obesity $[15,16]$. Immune cells and mainly macrophages infiltrate these tissues and produce pro-inflammatory cytokines, which act in an autocrine and paracrine manner to interfere with insulin signaling [16-18]. In fact, activation of inflammatory pathways in adipocytes impairs triglyceride storage and increases release of free fatty acids, exacerbating insulin resistance in muscle and liver [19]. Thus, chronic inflammation appears to be a clinically important change that occurs in adipose tissue when it becomes obese [20]. 
While in healthy individuals, the M2 macrophages population is present at high levels, in obesity, it switches to pro-inflammatory M1 macrophages leading to high expression levels of cytokines and chemokines [21]. Serum pro-inflammatory cytokines such as TNF- $\alpha$, IL-1 $\beta$ and IL-6 [22] as well as chemokines [23] were found elevated in obese and T2DM individuals.

\section{Inflammation and pancreatic islet $\beta$-cells}

Pancreatic $\beta$-cells are known to be particularly sensitive to damage induced by the immune system compared with the surrounding non $\beta$-cells, due in part to their low expression levels of cytoprotective enzymes [24]. While functional impairments in the $\beta$-cell are induced shortly after exposure to cytokines, apoptosis is detected after chronic exposure to the inflammatory mediators indicating that an active process is taking place, a race between deleterious and protective mechanisms where ultimately the deleterious prevails, leading to $\beta$-cell death. Therefore, $\beta$-cells play an active role in their own destruction by expressing high levels of cytokines, chemokines, proinflammatory mediators such as NF-kB, iNOS in response to diabetogenic agents [25]. In fact, increased evidence has emerged that supports a role for islet inflammation in the development of T2DM and not only in T1DM. In the islets of T2DM individuals, a higher number of infiltrated macrophages has been detected [26,27] and increased levels of cytokines and chemokines in obesity dependent diabetes were also reported $[22,23,28,29]$. Saturated fatty acids can induce $\beta$-cell death by apoptosis, whereas unsaturated fatty acids are usually protective [30]. Palmitate is the most common saturated FFA in man and has been used in in vitro studies to elucidate the mechanisms of lipotoxicity and has been implicated in palmitate-induced $\beta$-cell dysfunction and death [31-33].

Several mechanisms have been proposed to link inflammation and lipotoxicity with $\beta$-cells. Eguchi et al. [34] showed that exposure of $\beta$-cells to palmitate causes the production of chemokines such as CCL2/MCP1 and CXCL1/GR01 that recruit M1-type proinflammatory macrophages to the islets by activation of the TLR4/MyD88 pathway. Depletion of M1-type cells using clodronate protected mice from palmitate-induced $\beta$-cell dysfunction and inhibited the downregulation of $\beta$-cell specific genes in islets. Therefore, and as mentioned for the adipose tissue, a shift from M2 to M1 macrophages appears to occur. Laser capture microdissection was performed to isolate $\beta$-cells from pancreas sections of type 2 diabetic and of non-diabetic donors. Higher expression of the chemokines mainly CCL2/MCP-1 and CCL13/ MCP-4 was detected in T2DM islets [35]. A similar study was performed where the cytokines IL-1 $\beta$ and IL-8 were found to be also upregulated in T2DM islets compared to controls [36]. Altogether, these reports emphasize the active role the $\beta$-cell is playing in the activated inflammatory process leading to its loss of function and ultimately to its demise.

\section{Prostanoids and pancreatic islet $\beta$-cells}

The cyclooxygenase-2 (COX2) enzyme and its major product, the prostaglandin E2 (PGE2), have been implicated in the pathogenesis of several inflammatory diseases [37]. Results obtained using knock-out mouse studies, indicate that prostanoids including PGE2 exert both pro-inflammatory and anti-inflammatory responses, through regulation of gene expression in different tissues. In most tissues, Cox 1 is predominantly expressed relative to COX2. While the isoenzyme Cox1, is constitutively expressed in most mammalian tissues and is involved in maintaining physiological functions, the inducible COX2, is usually expressed at low levels in most tissues and cells, but is rapidly induced in response to a wide range of inflammatory stimuli [38]. Previous studies reported that COX2 is dominant in the HIT $\beta$-cell line and in human islets under basal condition [39,40]. COX2 expression was induced in human islets exposed to high glucose and was elevated in islets of $\mathrm{db} / \mathrm{db}$ mice, a mouse model of T2DM $[12,13]$. Importantly, we have recently shown that its expression is strongly upregulated in human islets exposed to the saturated FA palmitate as well as in islets of T2DM diabetic donors as compared to control individuals [41]. Differing results regarding the role of PGE2 on insulin secretion were reported. While a few studies showed that PGE2 inhibited glucose stimulated insulin secretion (GSIS) in HIT cells [42-44], others reported a lack of inhibitory effect on insulin secretion in rat $[45,46]$ and human islets $[45,47]$. The molecular mechanism of PGE2 effect on $\beta$-cell dysfunction in HIT cells, was suggested to be mediated through the activation of the JNK pathway and inhibition of the Akt pathway leading to nuclear accumulation of Fox01 and defective GSIS $[44,48]$. An in vitro study reported that treatment with the selective COX2 inhibitor, Celecoxib, increased insulin release in INS-1E cells [49] and in isolated mouse islets concomitant with the reduction in PGE2 production [50]. In vivo studies showed that the inhibitor, improved the impaired insulin secretion in C57BL/6 mice following glucose load [50]. Most importantly, transgenic mice overexpressing COX2 and microsomal PGE synthase 1 (mPGES-1) in $\beta$-cells, showed significant reduction in $\beta$-cell mass and severe hyperglycemia from 6 weeks of age [51]. The roles of COX2 and PGE2 in $\beta$-cell death were recently confirmed in human islets and in MIN6 $\beta$-cells [41].

PGE2 acts in an autocrine or paracrine manner and numerous physiological functions via binding to a family of four G-proteincoupled receptors (GPCRs) termed EP1, EP2, EP3, and EP4. The expression of the four subtypes of EPs varies between tissues and cell types and exhibit differences in signal transduction, tissue localization, and regulation of expression. It was suggested that activation of the EP1 receptor mediates $\mathrm{Ca} 2+$ mobilization. While the activation of the EP3 receptor usually inhibits adenylate cyclase and subsequently leads to a decrease in cAMP concentrations, that of EP2 and EP4 causes increases in intracellular cAMP levels [52]. Several lines of evidence suggest regulatory roles for PGE2 in islet functions through its receptors. In the HIT-T15 $\beta$-cell line, Robertson and associates [53] demonstrated the presence of PGE2 receptors in the cell membrane fraction and which were regulated by inhibitory component of adenylate cyclase. Before the PGE2 receptors subtypes were characterized, studies from the Laychock's group [54] demonstrated that Pertussis toxin (PTx) was able to reverse the PGE2-inhibition of GSIS, indicating the coupling to a PTx-sensitive G-protein (Gi). Stimulatory (Gs) and inhibitory (Gi) classes of heterotrimeric $G$ proteins, in the 
modulation of insulin secretion have been described in insulinsecreting cells $[55,56]$. In particular, PGE2 is suggested to activate the inhibitory class of trimeric G-proteins in insulin secreting cells $[57,58]$. The hetero-trimeric Gi protein $\alpha$-subunit, $\mathrm{G} \alpha \mathrm{z}$, was also shown to modulate a signaling pathway that is inhibitory to GSIS in INS1 cells by suppressing cAMP production [59]. Islets of null mice to this subunit showed significantly higher GSIS than those of wild-type mice and higher levels of cAMP even in the absence of exogenous stimulation [60]. Moreover, it was reported that among the EPs receptor, EP3 is the one whose expression is increased in islets from diabetic BTBR mice [61] and human cadaveric T2D donors, and the EP3 antagonists improved GSIS [41,61]. Blockade of EP3 was also shown to enhance $\beta$-cell proliferation in young, but not old, mouse islets and to increase human $\beta$-cell proliferation. We more recently showed that increased EP3 expression was observed in human islets and in MIN6 $\beta$-cells exposed to palmitate [62]. Downregulation of the pathway using pharmacological tools (inhibitor or antagonist) and the RNA interference approach to either COX2 or EP3 significantly decreased the levels of palmitateinduced apoptosis. The data suggest that the involvement of EP3 in PGE2- and palmitate-induced apoptosis is highly important for better understanding the lipotoxicity mechanisms in $\beta$-cells [41].

\section{Conclusion}

Based on the described inflammatory aspects shown to be associated with T2DM disease, anti-inflammatory therapies could have a place in the development of strategies aimed at preserving adequate $\beta$-cell mass and insulin production to limit the progression of the disease.

\section{Acknowledgement}

This work was supported in part by the grants from the Israel Science Foundation (ISF 1370/15) and the Israel Innovation Authority (63421).

\section{References}

1. Kahn BB (1998) Type 2 diabetes: when insulin secretion fails to compensate for insulin resistance. Cell 92(5): 593-596.

2. Unger RH (1995) Lipotoxicity in the pathogenesis of obesity-dependent NIDDM. Genetic and clinical implications. Diabetes 44(8): 863-870.

3. Rhodes CJ (2005) Type 2 diabetes-a matter of beta-cell life and death? Science 307(5708): 380-384.

4. Butler AE, Janson J, Bonner Weir S, Ritzel R, Rizza RA, et al. (2003) Betacell deficit and increased beta-cell apoptosis in humans with type 2 diabetes. Diabetes 52(1): 102-110.

5. Weir GC, Bonner Weir S (2013) Islet beta cell mass in diabetes and how it relates to function, birth, and death. Ann N Y Acad Sci 1281: 92-105.

6. DeFronzo RA (2010) Insulin resistance, lipotoxicity, type 2 diabetes and atherosclerosis: The missing links. The Claude Bernard Lecture 2009. Diabetologia 53(7): 1270-1287.

7. Haus JM, Kashyap SR, Kasumov T, Zhang R, Kelly KR, et al. (2009) Plasma ceramides are elevated in obese subjects with type 2 diabetes and correlate with the severity of insulin resistance. Diabetes 58(2): 337343.

8. Boden G, Shulman GI (2002) Free fatty acids in obesity and type 2 diabetes: defining their role in the development of insulin resistance and beta-cell dysfunction. Eur J Clin Invest 32(3): 14-23.
9. Carpentier A, Mittelman SD, Lamarche B, Bergman RN, Giacca A, et al. (1999) Acute enhancement of insulin secretion by FFA in humans is lost with prolonged FFA elevation. Am J Physiol 276(6): E1055-E1066.

10. Pankow JS, Duncan BB, Schmidt MI, Ballantyne CM, Couper DJ, et al. (2004) Fasting plasma free fatty acids and risk of type 2 diabetes: the atherosclerosis risk in communities study. Diabetes Care 27(1):77-82.

11. Kashyap S, Belfort R, Gastaldelli A, Pratipanawatr T, Berria R, et al. (2003) A sustained increase in plasma free fatty acids impairs insulin secretion in nondiabetic subjects genetically predisposed to develop type 2 diabetes. Diabetes 52(10): 2461-2474.

12. Cnop M, Ladriere L, Igoillo Esteve M, Moura RF, Cunha DA (2010) Causes and cures for endoplasmic reticulum stress in lipotoxic beta-cell dysfunction. Diabetes Obes Metab 12(2): 76-82.

13. Poitout V, Amyot J, Semache M, Zarrouki B, Hagman D, et al. (2010) Glucolipotoxicity of the pancreatic beta cell. Biochim Biophys Acta 1801(3): 289-298.

14. Ly LD, Xu S, Choi SK, Ha CM, Thoudam T, et al. (2017) Oxidative stress and calcium dysregulation by palmitate in type 2 diabetes. Exp Mol Med 49(2): e291.

15. Shoelson SE, Lee J, Goldfine AB (2006) Inflammation and insulin resistance. J Clin Invest 116(7): 1793-1801.

16. Esser N, Legrand Poels S, Piette J, Scheen AJ, Paquot N (2014) Inflammation as a link between obesity, metabolic syndrome and type 2 diabetes. Diabetes Res Clin Pract 105(2): 141-150.

17. Weisberg SP, McCann D, Desai M, Rosenbaum M, Leibel RL, et al. (2003) Obesity is associated with macrophage accumulation in adipose tissue. J Clin Invest 112(12): 1796-1808.

18. Khodabandehloo H, Firuzjaee SG, Panahi G, Meshkani R (2016) Molecular and cellular mechanisms linking inflammation to insulin resistance and beta-cell dysfunction. Transl Res 167(1): 228-256.

19. Guilherme A, Virbasius JV, Puri V, Czech MP (2008) Adipocyte dysfunctions linking obesity to insulin resistance and type 2 diabetes. Nat Rev Mol Cell Biol 9(5): 367-377.

20. Hotamisligil GS, Erbay E (2008) Nutrient sensing and inflammation in metabolic diseases. Nat Rev Immunol 8(12): 923-934.

21. Satoh N, Shimatsu A, Himeno A, Sasaki Y, Yamakage H, et al. (2010) Unbalanced M1/M2 phenotype of peripheral blood monocytes in obese diabetic patients: Effect of pioglitazone. Diabetes Care 33(1): e7.

22. Spranger J, Kroke A, Mohlig M, Hoffmann K, Bergmann MM, et al. (2003) Inflammatory cytokines and the risk to develop type 2 diabetes: results of the prospective population-based European Prospective Investigation into Cancer and Nutrition (EPIC)-Potsdam Study. Diabetes 52(3): 812817.

23. Herder C, Baumert J, Thorand B, Koenig W, de Jager W, et al. (2006) Chemokines as risk factors for type 2 diabetes: results from the MONICA/ KORA Augsburg study, 1984-2002. Diabetologia 49(5): 921-929.

24. Lenzen S, Drinkgern J, Tiedge M (1996) Low antioxidant enzyme gene expression in pancreatic islets compared with various other mouse tissues. Free Radic Biol Med 20(3): 463-466.

25. Eldor R, Yeffet A, Baum K, Doviner V, Amar D, et al. (2006) Conditional and specific NF-kappaB blockade protects pancreatic beta cells from diabetogenic agents. Proc Natl Acad Sci U S A 103(13): 5072-5077.

26. Ehses JA, Perren A, Eppler E, Ribaux P, Pospisilik JA, et al. (2007) Increased number of islet-associated macrophages in type 2 diabetes. Diabetes 56(9): 2356-2370.

27. Richardson SJ, Willcox A, Bone AJ, Foulis AK, Morgan NG (2009) Isletassociated macrophages in type 2 diabetes. Diabetologia 52(8): 16861688.

28. Donath MY, Schnetzler BM, Ellingsgaard H, Ehses JA (2009) Islet inflammation impairs the pancreatic beta-cell in type 2 diabetes. Physiology (Bethesda) 24: 325-331. 
29. Pradhan AD, Manson JE, Rifai N, Buring JE, Ridker PM (2001) C-reactive protein, interleukin 6 , and risk of developing type 2 diabetes mellitus. Jama 286(3): 327-334.

30. Palomer X, Pizarro Delgado J, Barroso E, Vazquez Carrera M (2018) Palmitic and oleic acid: The yin and yang of fatty acids in type 2 diabetes mellitus. Trends Endocrinol Metab 29(3): 178-190.

31. El Assaad W, Buteau J, Peyot ML, Nolan C, Roduit R, et al. (2003) Saturated fatty acids synergize with elevated glucose to cause pancreatic beta-cell death. Endocrinology 144(9): 4154-4163.

32. Lupi R, Dotta F, Marselli L, Del Guerra S, Masini M, et al. (2002) Prolonged exposure to free fatty acids has cytostatic and pro-apoptotic effects on human pancreatic islets: evidence that beta-cell death is caspase mediated, partially dependent on ceramide pathway, and Bcl-2 regulated. Diabetes 51(5): 1437-1442.

33. Acosta Montano P, Garcia Gonzalez V (2018) Effects of dietary fatty acids in pancreatic beta cell metabolism, implications in homeostasis. Nutrients 10(4).

34. Eguchi K, Manabe I, Oishi Tanaka Y, Ohsugi M, Kono N, et al. (2012) Saturated fatty acid and TLR signaling link beta cell dysfunction and islet inflammation. Cell Metab 15(4): 518-533.

35. Igoillo Esteve M, Marselli L, Cunha DA, Ladriere L, Ortis F, et al. (2010) Palmitate induces a pro-inflammatory response in human pancreatic islets that mimics CCL2 expression by beta cells in type 2 diabetes. Diabetologia 53(7): 1395-1405.

36. Schnetzler BM, Thorne J, Parnaud G, Marselli L, Ehses JA, et al. (2008) Increased interleukin (IL)-1beta messenger ribonucleic acid expression in beta -cells of individuals with type 2 diabetes and regulation of IL1 beta in human islets by glucose and autostimulation. J Clin Endocrinol Metab 93(10): 4065-4074.

37. Dubois RN, Abramson SB, Crofford L, Gupta RA, Simon LS, et al. (1998) Cyclooxygenase in biology and disease. Faseb J 12(12): 1063-1073.

38. Smith WL, DeWitt DL, Garavito RM (2000) Cyclooxygenases: structural, cellular, and molecular biology. Annu Rev Biochem 69: 145-182.

39. Robertson RP (1998) Dominance of cyclooxygenase-2 in the regulation of pancreatic islet prostaglandin synthesis. Diabetes 47(9): 1379-1383.

40. Sorli CH, Zhang HJ, Armstrong MB, Rajotte RV, Maclouf J, et al. (1998) Basal expression of cyclooxygenase-2 and nuclear factor-interleukin 6 are dominant and coordinately regulated by interleukin 1 in the pancreatic islet. Proc Natl Acad Sci U S A 95(4): 1788-1793.

41. Amior L, Srivastava R, Nano R, Bertuzzi F, Melloul D (2019) The role of Cox-2 and prostaglandin $\mathrm{E}_{2}$ receptor EP3 in pancreatic beta-cell death. FASEB J 33(4): 4975-4986.

42. Robertson RP, Tsai P, Little SA, Zhang HJ, Walseth TF (1987) Receptormediated adenylate cyclase-coupled mechanism for $\mathrm{PGE}_{2}$ inhibition of insulin secretion in HIT cells. Diabetes 36(9): 1047-1053.

43. Seaquist ER, Walseth TF, Nelson DM, Robertson RP (1989) Pertussis toxin-sensitive $\mathrm{G}$ protein mediation of $\mathrm{PGE}_{2}$ inhibition of cAMP metabolism and phasic glucose-induced insulin secretion in HIT cells. Diabetes 38(11): 1439-1445.

44. Meng ZX, Sun JX, Ling JJ, Lv JH, Zhu DY, et al. (2006) Prostaglandin $E_{2}$ regulates Foxo activity via the Akt pathway: implications for pancreatic islet beta cell dysfunction. Diabetologia 49(12): 2959-2968.

45. Heitmeier MR, Kelly CB, Ensor NJ, Gibson KA, Mullis KG, et al. (2004) Role of cyclooxygenase- 2 in cytokine-induced beta-cell dysfunction and damage by isolated rat and human islets. J Biol Chem 279(51): 5314553151.
46. Zawalich WS, Zawalich KC, Yamazaki H (2007) Divergent effects of epinephrine and prostaglandin $\mathrm{E}_{2}$ on glucose-induced insulin secretion from perifused rat islets. Metabolism 56(1): 12-18.

47. Persaud SJ, Muller D, Belin VD, Papadimitriou A, Huang GC, et al. (2007) Expression and function of cyclooxygenase and lipoxygenase enzymes in human islets of Langerhans. Arch Physiol Biochem 113(3): 104-109.

48. Meng Z, Lv J, Luo Y, Lin Y, Zhu Y, et al. (2009) Forkhead box 01/pancreatic and duodenal homeobox 1 intracellular translocation is regulated by c-Jun $\mathrm{N}$-terminal kinase and involved in prostaglandin $\mathrm{E}_{2}$-induced pancreatic beta-cell dysfunction. Endocrinology 150(12): 5284-5293.

49. Luo C, Kallajoki M, Gross R, Mulari M, Teros T, et al. (2002) Cellular distribution and contribution of cyclooxygenase COX-2 to diabetogenesis in NOD mouse. Cell Tissue Res 310(2): 169-175.

50. Fujita H, Kakei M, Fujishima H, Morii T, Yamada Y, et al. (2007) Effect of selective cyclooxygenase-2 (COX-2) inhibitor treatment on glucosestimulated insulin secretion in C57BL/6 mice. Biochem Biophys Res Commun 363(1): 37-43.

51. Oshima H, Taketo MM, Oshima M (2006) Destruction of pancreatic betacells by transgenic induction of prostaglandin $\mathrm{E}_{2}$ in the islets. J Biol Chem 281(39): 29330-29336.

52. Regan JW, Bailey TJ, Pepperl DJ, Pierce KL, Bogardus AM, et al. (1994) Cloning of a novel human prostaglandin receptor with characteristics of the pharmacologically defined EP2 subtype. Mol Pharmacol 46(2): 213220 .

53. Robertson RP (1988) Eicosanoids as pluripotential modulators of pancreatic islet function. Diabetes 37(4): 367-370.

54. Laychock SG (1989) Prostaglandin $E_{2}$ inhibits phosphoinositide metabolism in isolated pancreatic islets. Biochem J 260(1): 291-294.

55. Kowluru A (2010) Small G proteins in islet beta-cell function. Endocr Rev 31(1): 52-78.

56. Robertson RP, Seaquist ER, Walseth TF (1991) G proteins and modulation of insulin secretion. Diabetes 40(1): 1-6.

57. Kowluru A, Li G, Metz SA (1997) Glucose activates the carboxyl methylation of gamma subunits of trimeric GTP-binding proteins in pancreatic beta cells. Modulation in vivo by calcium, GTP, and pertussis toxin. J Clin Invest 100(6): 1596-1610.

58. Kowluru A, Metz SA (1994) Stimulation by prostaglandin $\mathrm{E}_{2}$ of a highaffinity GTPase in the secretory granules of normal rat and human pancreatic islets. Biochem J 297(2): 399-406.

59. Kimple ME, Nixon AB, Kelly P, Bailey CL, Young KH, et al. (2005) A role for $\mathrm{G}(\mathrm{z})$ in pancreatic islet beta-cell biology. J Biol Chem 280(36): 3170831713.

60. Kimple ME, Joseph JW, Bailey CL, Fueger PT, Hendry IA, et al. (2008) Galphaz negatively regulates insulin secretion and glucose clearance. J Biol Chem 283(8): 4560-4567.

61. Kimple ME, Keller MP, Rabaglia MR, Pasker RL, Neuman JC, et al. (2013) Prostaglandin $\mathrm{E}_{2}$ receptor, EP3, is induced in diabetic islets and negatively regulates glucose- and hormone-stimulated insulin secretion. Diabetes 62(6): 1904-1912.

62. Carboneau BA, Allan JA, Townsend SE, Kimple ME, Breyer RM, et al. (2017) Opposing effects of prostaglandin $E_{2}$ receptors EP3 and EP4 on mouse and human beta-cell survival and proliferation. Mol Metab 6(6): 548-559. 